\title{
SCREENING OF MALIGNANT HYPERTHERMIA SUSCEPTIBLE FAMILIES BY CREATINE PHOSPHOKINASE MEASUREMENT AND OTHER CLINICAL INVESTIGATIONS
}

\author{
Beverley A. Britt, ${ }^{1,2}$ Laszlo Endreny ${ }^{2}{ }^{2}$ Pearl L. Peters, ${ }^{1}$ \\ Francis H.-F. Kwong, ${ }^{2}$ and LJUJ Jana Kadijevic ${ }^{3}$
}

\section{INTRODUCTION}

Creatine phosphokinase, on CPK, is an enzyme of muscle and nervous tissue. By far the largest portion is located in muscle, especially in the skeletal muscle. ${ }^{1-4}$ Within the muscle cell CPK is found not only in the cytoplasm but also in the sarcoplasmic reticulum ${ }^{5}$ and in the mitochondria. ${ }^{6}$ The normal function of CPK is to catalyze the reversible interaction between creatine phosphate (CP) and adenosine diphosphate (ADP) (on the left, Figures $l a$ and $1 b$ ) and adenosine triphosphate (ATP) and creatine (on the right, Figures $1 a$ and $1 b$ ). This interchange is known as the Lohmann reaction. ${ }^{7}$ During muscle rest the reaction proceeds to the left with the formation of ADP and high energy CP. ADP in turn is phosphorylated within the mitochondrion to ATP (Figure $1 a$ ). During muscle exercise, myosin ATPase in the presence of calcium $\left(>5 \times 10^{-7} \mathrm{M}\right)$ catalyzes hydrolysis of ATP to ADP and phosphate, with the release of energy which is utilized in myofibrillar contraction. The ADP, which is thereby accumulated, forces the Lohmann reaction to the right, so reforming ATP - the substrate essential for myosin ATPase ${ }^{8-18}$ (Figure $1 b)$. CPK may play a similar energy-sustaining role in the sarcoplasmic reticuIum and mitochondria by maintaining ATP supplies necessary to maintain active ion transport across the membranes of these organelles. ${ }^{5,6}$

Any disease, trauma or drug which damages the sarcolemma permits CPK to leak across this injured membrane to the serum. For example, various investigators have reported that serum CPK concentrations have been elevated following unaccustomed muscle exercise ${ }^{19,20}$ and acute myocardial infarction. ${ }^{21-23}$ High levels have also been seen in various myopathies, ${ }^{21-28}$ for instance muscular dystrophy, neurological disorders, ${ }^{21,28-31}$ paranoid schizophrenia, ${ }^{21,32}$ acute alcoholism, ${ }^{21,33}$ hypothyroidism ${ }^{21,34,35}$ and after administration of certain antibiotics, ${ }^{36}$ muscle relaxants ${ }^{37,38}$ and surgical and diagnostic procedures..$^{39}$ All these conditions are thought to be associated, at least to some extent, with muscle damage.

Denborough, et al. ${ }^{40,41}$ first demonstrated that serum CPK was higher than normal in patients who had recovered from an acute malignant hyperthermic $(\mathrm{MH})$ crisis. He found, additionally, that some relatives of afflicted patients likewise had raised serum CPK. These relatives had not had $M H$ reactions and in them the high serum CPK could not be due to chronic muscle damage incurred at the time of the crisis. Denborough also noted that other enzymes normally located in

From the Departments of Anaesthesia ${ }^{1}$ and Pharmacology, ${ }^{2}$ University of Toronto, and Department of Biochemistry, Toronto General Hospital.3 

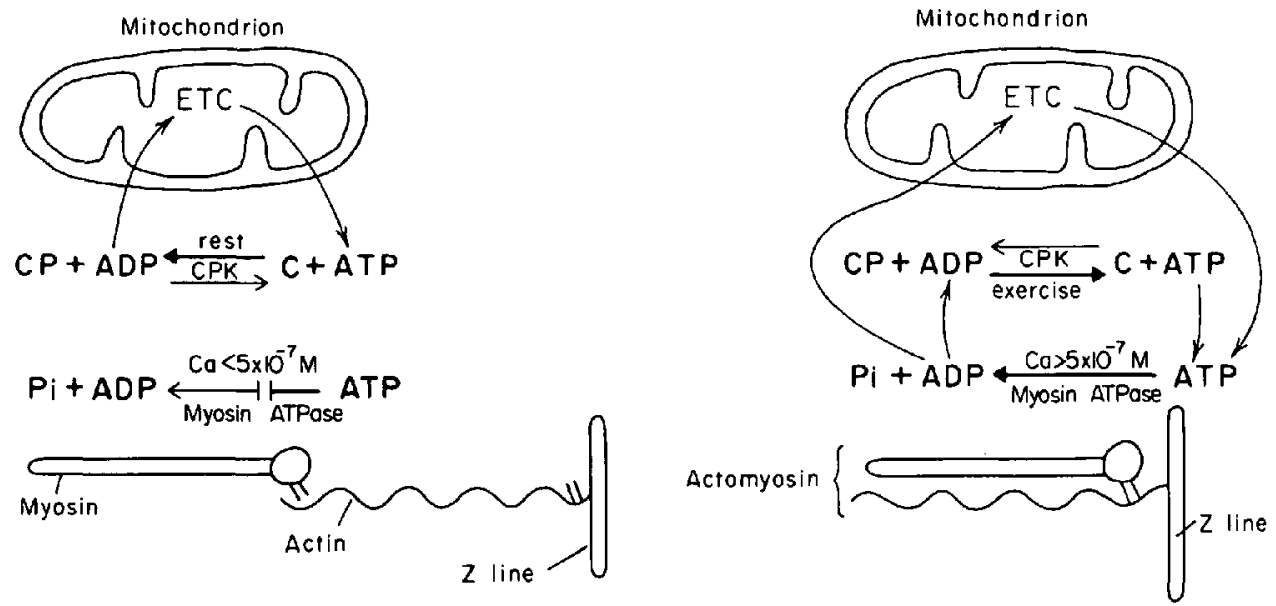

FIgUREs $1 a$ and $1 b$ : Role of creatine phosphokinase (CPK) in maintaining the energy balance $(a)$ in resting and $(b)$ in exercising muscle. The symbols applied are:

ADP - Adenosine diphosphate

ATP - Adenosine triphosphate

ATPase - Adenosine triphosphatase

C - Creatine

$\mathrm{CP}$ - Creatine phosphate

$\mathrm{Pi}$ - Inorganic phosphate

$\mathrm{Ca}-$ Free myoplasmic calcium concentration

ETC - Electron transport chain.

skeletal muscle (e.g. glutamic oxalic transaminase (GOT), lactic dehydrogenase (LDH) and aldolase were also elevated in the serum of these patients.

These observations were significant for two reasons. Firstly, they shed further light on the aetiology of $\mathrm{MH}$, since excessive leakage of $\mathrm{CPK}$ out of muscle prior to or after recovery from anaesthesia suggested that the defect involved an impairment of the integrity of the sarcolemma. Secondly, it was hoped that CPK screening of relatives of $\mathrm{MH}$ patients would provide a simple, cheap, and readily available diagnostic tool. Unfortunately, subsequent reports by other investigators were not so sanguine and some were frankly contradictory. While Isaacs and Barlow, ${ }^{42-45}$ Aldrete, et al., ${ }^{46}$ Moulds and Denborough, ${ }^{47}$ Zsigmond, et al., ${ }^{48}$ Kyei-Mensah, et $a l .{ }^{49}$ Larard, et al., ${ }^{50}$ and Wedley and Jaffe ${ }^{51}$ felt that the CPK was a useful indicator of $\mathrm{MH}$, others such as Ellis, et al., ${ }^{52,53}$ Moulds and Denborough ${ }^{54}$ and Kelstrup, et al. ${ }^{55}$ found, on the contrary, that correlation between an elevated CPK and a previous MH episode or a positive muscle biopsy was poor. Each of these studies, however, was carried out on comparatively small numbers of test subjects from only one, or at most, a very few families. Moreover, sampling techniques between and within studies were not always uniform. Finally, King, et al. ${ }^{56}$ discovered several malignant hyperthermia susceptible (MHS) families in which serum CPK values were normal in all relatives studied.

We would, therefore, like to report our study of the serum CPK, LDH, GOT, clinical muscle abnormalities, and previous anaesthetic histories of many patients from a large number of families.

\section{METHODS}

In all, we examined 1,802 individuals from 56 families. The number of persons seen in each family ranged from one to 412 . One hundred and twenty-four patients 
TABLE I

MH Crises in Affected Families

\begin{tabular}{cc}
\hline $\begin{array}{c}\text { Number of } \\
\text { cases per } \\
\text { family }\end{array}$ & $\begin{array}{c}\text { Number } \\
\text { of } \\
\text { families }\end{array}$ \\
\hline 1 & 32 \\
2 & 15 \\
3 & 5 \\
4 & 1 \\
5 & 2 \\
11 & 1 \\
22 & 1 \\
\hline
\end{tabular}

had had MH crises, of whom we were able to test 72 . The number of $\mathrm{MH}$ crises per family ranged from one to 22 (Table I). Of those individuals who had had $\mathrm{MH}$ crises, a maximum of eight in one family were actually interviewed and examined. Normal volunteers, 445 in number, consisted of laboratory and hospital personnel, their friends and families, families undergoing investigation for plasma cholinesterase deficiency, spouses of MHS patients and their relatives and adopted children within MHS families.

\section{Patient Visiting}

All these subjects were seen either in our laboratory or in their own homes. The latter (especially for the MH families) proved to be the more desirable, as there it frequently proved possible to collect the majority of a family together on the same day. This was often not feasible in the laboratory, situated as it frequently was several hundred miles away from the families' main locale. Such a home-visiting arrangement not only considerably accelerated the sampling process, but also greatly facilitated collection of the family tree data necessary for construction of pedigrees which, for some of the larger families, were quite complex.

During the first visit, each person was questioned regarding number of previous anaesthetics and signs of malignant hyperthermia during such anaesthetics. Each individual was also questioned and examined for evidence of muscle abnormalities, for example, muscle cramps, hernias, joint hypermobility, kyphoscoliosis, increased muscle volume and strength, myopathy, ptosis and squint. On this first visit, as well as on each of two subsequent visits, a blood sample was taken from each person for CPK, LDH and GOT determinations.

\section{Blood Sampling}

We found that reproducibility of CPK measurements could be considerably improved by using meticulous care in our blood sampling techniques. First, the patients were advised not to engage in any strenuous physical activity for five days, and not to consume alcohol for one day prior to our visit. Where possible, blood was removed only during the later part of the afternoon. For some of the larger families, however, this latter stricture was not always feasible. To prevent hypoxia in the forearm, the tourniquet was applied with minimal pressure and for as brief a period prior to venipuncture as possible. As soon as blood appeared in the syringe, 
the tourniquet was removed. To minimize haemolysis, a wide bore needle was employed. After removal from the patient's vein the needle was detached from the syring and the stopper was removed from the test tube. The tube was held at an angle and the blood was poured gently down the inside of its lower wall. Forceful suction of blood into a vacuum tube was never permitted. The samples were immediately placed in the dark, since light is known to rapidly accelerate decomposition of CPK. ${ }^{57}$ As soon as coagulation occurred, a few grains of Plas-Aid (plastic granules) were sprinkled on top of the clot. Plas-Aid forced the clot evenly downward during centrifuging, thus ensuring better separation of serum from red cells. The tubes were centrifuged for twelve minutes at 2,000 r.p.m. Higher speeds were found to produce haemolysis. The supernatant was removed with a Pasteur pipette, and the serum was frozen in dry ice. Various studies have shown that CPK, maintained at this temperature, deteriorates only at a very slow rate. ${ }^{57}$ Dry ice freezing permitted samples to be stored safely for several days prior to measurement.

\section{Biochemical Techniques}

Serum creatine phosphokinase was measured by a modification of Rosalki's method. ${ }^{58}$ Enzyme activity was determined by measuring the rate of reduction of NADP at $340 \mathrm{~nm}$, at $25^{\circ} \mathrm{C}$, using a Gilford 2000 recording spectrophotometer. $^{8}$

The reaction was measured in three steps as follows:

$$
\begin{aligned}
& \text { creatine phosphate }+ \text { ADP } \stackrel{\mathrm{CPK}}{\longrightarrow} \text { creatine }+ \text { ATP } \\
& \text { ATP + glucose } \stackrel{\text { hexokinase }}{\longrightarrow} \text { G-6-P + ADP } \\
& \text { G-6-P + NADP } \stackrel{\text { G-6-PDH }}{\longrightarrow} \mathrm{NADPH}_{2}+6 \text {-phosphogluconate. }
\end{aligned}
$$

Calbiochem CPK Fast-Pack reagents were used to provide the buffered substrates and NADP. ${ }^{59}$ Dithiothreitol was added to activate the enzyme.

Serum GOT was determined by a modification of the Technicon N-25b automated method based on the procedure of Morgenstern, et al. ${ }^{60}$ Oxaloacetate produced by the action of the enzyme was dialyzed and then reacted with the diazonium salt, Azoene Fast Red. The product was measured colorimetrically at 340 $\mathrm{mm}$ at $37^{\circ} \mathrm{C}$.

The reaction was determined in two steps as follows:

$$
\begin{aligned}
& \text { aspartate }+\alpha \text {-ketoglutarate } \stackrel{\text { GOT }}{\longleftrightarrow} \text { oxaloacetate }+ \text { glutamate } \\
& \text { oxaloacetate }+ \text { azoene fast red } \longleftrightarrow \text { coloured product. }
\end{aligned}
$$

Serum LDH was measured by a modification of the kinetic method described by Wroblewski and LaDue. ${ }^{61}$ Enzyme activity was determined by measuring the rate of oxidation of $\mathrm{NADH}_{2}$, with pyruvate as substrate, at $340 \mathrm{~nm}\left(25^{\circ} \mathrm{C}\right)$ using a Gilford 2000 recording spectrophotometer.

The reaction was measured in a single step as follows:

$$
\text { pyruvate }+\mathrm{NADH}_{2} \stackrel{\mathrm{LDH}}{\longrightarrow} \text { lactate }+\mathrm{NAD} \text {. }
$$




\section{Statistical Evaluation}

Statistical analysis was carried out on the biochemical and muscle data. For this purpose, the patients were divided into four categories:

1. MHS - those who had had a previous MH crisis;

2. first-degree relatives - parents, siblings and children of MHS patients;

3. second- and third-degree relatives - grandparents, great-grandparents, grandchildren, great-grandchildren, aunts, uncles, great-aunts, great-uncles, first cousins, nephews, nieces, grand-nephews and grand-nieces;

4. normal volunteers - unrelated to any individual in a known or suspected MHS family.

Since the observed standard deviations were approximately proportional to the corresponding averages (for example, in Tables II, IV, and V), all reported statistical tests were based on logarithmically transformed variables. The same tests were, however, performed also with the original observations: the transformation did not affect the qualitative conclusions.

\section{Results and Discussion}

\section{Factors influencing creatine phosphokinase (CPK) levels}

The serum CPK proved to be the best indicator of the MH trait. Thus, the mean and maximum serum GOTs and LDHs were only slightly higher in the MHS patients than in the normal volunteers (Tables II $a, b$ ). The serum CPK, on the other hand, was substantially higher in the MHS individuals than in the normal

TABLE IIA

Mean Serum CPK, GOT, and LDH in MHS Patients, in Relatives of MHS Patients, and in Normal Subjects

\begin{tabular}{lccc}
\hline & CPK & GOT & LDH \\
\hline MHS patients & $127.1^{*}$ & 36.2 & 197.9 \\
& $(130.7) \dagger$ & $(16.1)$ & $(69.1)$ \\
& $(15.4) \ddagger$ & $(2.8)$ & $(11.7)$ \\
1st degree relatives & $(72) \S$ & $(33)$ & $(35)$ \\
& 77.4 & 34.7 & 167.2 \\
& $(97.2)$ & $(16.7)$ & $(67.3)$ \\
& $(6.0)$ & $(2.7)$ & $(9.2)$ \\
2nd and 3rd degree relatives & 54.2 & $(39)$ & $(54)$ \\
& $(49.7)$ & 21.2 & $(10.3)$ \\
& $(2.3)$ & $(2.5)$ & $(36.2)$ \\
& $(466)$ & $(17)$ & $(5.2)$ \\
Normal subjects & 40.7 & 25.2 & $(48)$ \\
& $(25.7)$ & $(8.2)$ & $(39.4$ \\
& $(1.2)$ & $(0.6)$ & $(2.5)$ \\
& $(445)$ & $(172)$ & $(197)$ \\
\hline
\end{tabular}

*Weighted means (in international units).

†S.D. (standard deviation).

†S.E.M. (standard error of mean).

$\S$ Number of subjects. 
TABLE IIB

Maximum Serum CPK, GOT and LDH in MHS Patients, in Relatives of MHS Patients and in NoRmal Subjects

\begin{tabular}{lccc}
\hline \hline & CPK & GOT & LDH \\
\hline MHS patients & $152.8^{*}$ & 41.2 & 211.9 \\
& $(158.5) \dagger$ & $(21.1)$ & $(82.2)$ \\
& $(18.7) \dagger$ & $(3.7)$ & $(13.9)$ \\
& $(72) \S$ & $(33)$ & $(35)$ \\
1st degree relatives & 93.1 & 35.7 & 180.6 \\
& $(121.1)$ & $(17.4)$ & $(73.9)$ \\
& $(7.5)$ & $(2.8)$ & $(10.1)$ \\
& $(259)$ & $(39)$ & $(54)$ \\
2nd and 3rd degree relatives & 61.6 & 21.4 & 143.4 \\
& $(61.8)$ & $(11.4)$ & $(43.7)$ \\
& $(2.9)$ & $(2.8)$ & $(6.3)$ \\
& $(466)$ & $(17)$ & $(48)$ \\
Normal subjects & 43.3 & 25.7 & 132.8 \\
& $(29.9)$ & $(9.3)$ & $(35.8)$ \\
& $(1.4)$ & $(0.7)$ & $(2.6)$ \\
& $(445)$ & $(172)$ & $(197)$ \\
\hline
\end{tabular}

* Mean of maximum values (in international units).

†S.D. (standard deviation).

tS.E.M. (standard error of mean).

$\S$ Number of subjects.

subjects (Tables II $a, b$ ). CPK levels for the near and distant relatives were intermediate between the normal and MHS patients.

In addition to the standard errors (Tables $\mathrm{II} a, \mathrm{~b}$ ), the variances of replicate observations within subjects (see below) also increased on the whole progressively from the normal volunteers through the distant and close relatives to the affected patients. This observation may reflect a generally increased variability associated with larger magnitudes of measurements. However, it may also support the hypothesis that the sarcolemma of MH patients is excessively fragile, so that the amount of CPK leaking outward across this membrane fluctuates to a greater than normal extent between subjects, depending on differences in severity of the inherent defect and also on variations in physical activity in individual subjects.

A more detailed analysis (Table III) based on analyses of variance indicates that variances of logarithmically transformed replicate observations within subjects (estimated by MS (error) in the tabulation) are approximately the same in the various groups. This implies, confirmed by direct analysis, that the standard deviation from this error component increases proportionately to the mean and, therefore, that it is high in patients, generally intermediate in relatives, and low in control subjects. In contrast, subject to subject variability of even the logarithmic observations (represented by MS (subjects) in Table III) increases from controls to relatives to probands.

This is mirrored by the F-statistics which contrast the two error components. All F-values are statistically highly significant. This indicates merely that temporal changes of CPK, GOT or LDH levels within subjects do not account entirely for the variability among individuals. Still, in control subjects, the F-value is small enough to suggest that these enzyme levels fluctuate very substantially. Therefore, a single measurement in a healthy person provides quite inadequate indication of the 
TABLE III

Variabilities Among and Within Subjects*

\begin{tabular}{|c|c|c|c|c|}
\hline & $\begin{array}{c}\text { MHS } \\
\text { patients }\end{array}$ & $\begin{array}{l}\text { 1st degree } \\
\text { relatives }\end{array}$ & $\begin{array}{c}\text { 2nd and } 3 r d \\
\text { degree } \\
\text { relatives }\end{array}$ & $\begin{array}{l}\text { Normal } \\
\text { subjects }\end{array}$ \\
\hline $\begin{array}{l}C P K \\
\text { MS (subjects) } \uparrow \\
\text { MS (error) } \ddagger \\
\text { df (subjects) } \$ \\
\text { df (error)\| } \\
\text { Fq }\end{array}$ & $\begin{array}{r}0.3207 \\
0.0275 \\
71 \\
122 \\
11.65\end{array}$ & $\begin{array}{r}0.2126 \\
0.0397 \\
258 \\
240 \\
5.35\end{array}$ & $\begin{array}{r}0.1215 \\
0.0318 \\
465 \\
338 \\
3.82\end{array}$ & $\begin{array}{r}0.0571 \\
0.0172 \\
444 \\
217 \\
3.32\end{array}$ \\
\hline $\begin{array}{l}\text { GOT } \\
\text { MS (subjects) } \\
\text { MS (error) } \\
\text { df (subjects) } \\
\text { df (error) } \\
\text { F }\end{array}$ & $\begin{array}{r}0.0687 \\
0.0084 \\
32 \\
51 \\
8.16\end{array}$ & $\begin{array}{r}0.0548 \\
0.0068 \\
38 \\
21 \\
8.07\end{array}$ & 一 & $\begin{array}{r}0.0174 \\
0.0074 \\
171 \\
42 \\
2.33\end{array}$ \\
\hline $\begin{array}{l}\text { LDH } \\
\text { MS (subjects) } \\
\text { MS (error) } \\
\text { df (subjects) } \\
\text { df (error) } \\
\text { F }\end{array}$ & $\begin{array}{r}0.0543 \\
0.0041 \\
34 \\
52 \\
13.20\end{array}$ & $\begin{array}{r}0.0392 \\
0.0119 \\
53 \\
37 \\
3.29\end{array}$ & - & $\begin{array}{r}0.0133 \\
0.0052 \\
196 \\
69 \\
2.56\end{array}$ \\
\hline
\end{tabular}

*Based on analyses of variance of the logarithmic observations.

†Mean square among subjects. It estimates the subject-to-subject variance (a measure of variability of the observations).

fError mean square. It estimates the variance of repeated observations within subjects.

\$Degrees of freedom for variance among subjects. They equal the number of subjects minus one.

Degrees of freedom for variance within subjects.

TF-statistic with degrees of freedom of df (Subjects) and df (Error). It compares MS (Subjects) with MS (Error) and, therefore, it characterizes statistically the importance of the variability among subjects.

disposition of his/her over-all average in the distribution of such readings in similarly healthy subjects. This is not so in affected patients or their close relatives whose enzyme levels are at any time at least indicative of deviations from the population average and thereby from the normal levels.

The percentage difference between the CPK levels of the two sexes tends to persist independently of the presence or absence of the $\mathrm{MH}$ trait or of the proximity of relatives to the affected subjects (Table IV). However, in MHS individuals this difference is not significant statistically. This probably reflects that, as seen above, the variability between these subjects does not exceed substantially that found within the individuals. This reduction in sex difference in serum CPK concentration in MHS patients may be due to masking by $\mathrm{MH}$ induced muscle membrane injury.

In normal persons (except for slightly higher levels in children) age had little effect on the CPK (Figure 2). In MHS patients, the CPK rose quite steeply from childhood through to the fortieth year, then fell in middle and old age to values similar to those observed in childhood. At the extremes of age, childhood and old age (i.e. during the periods of least physical strength), serum CPK values in MHS individuals were only slightly higher than in normal persons. During adolescence and early adult life (i.e. during the years of greatest muscle strength) the elevation of the serum CPK in MHS patients was maximal. 
TABLE IV

Dependence of Maximum Serum CPK on Sex

\begin{tabular}{lccc}
\hline \hline & Male & Female & t \\
\hline MHS patients & $174.3 \dagger$ & 125.9 & $1.50 \mathrm{n.s}$. \\
& $(177.0) \ddagger$ & $(129.5)$ & \\
& $(28.0) \S$ & $(22.9)$ & \\
1st degree relatives & 96.2 & $(32)$ & \\
& $(96.8)$ & 89.5 & $3.01^{\text {** }}$ \\
& $(8.2)$ & $(144.3)$ & \\
2nd and 3rd degree & $(138)$ & $(121)$ & \\
relatives & 75.7 & 47.8 & \\
& $(77.6)$ & $(35.8)$ & \\
& $(5.1)$ & $(2.3)$ & \\
Normal subjects & $(231)$ & $(235)$ & \\
& 50.0 & 37.8 & $5.75^{* * *}$ \\
& $(37.3)$ & $(20.6)$ & \\
& $(2.6)$ & $(1.3)$ & \\
\hline
\end{tabular}

IStatistical tests (t-values) are based on comparison of the logarithmic values.

† Mean of maximum value (in international units).

tStandard deviation.

Standard error of mean.

Number of subjects.

n.s. $P \geqslant 0.05$, not significant.

** $P<0.01$

***P $P<0.001$.

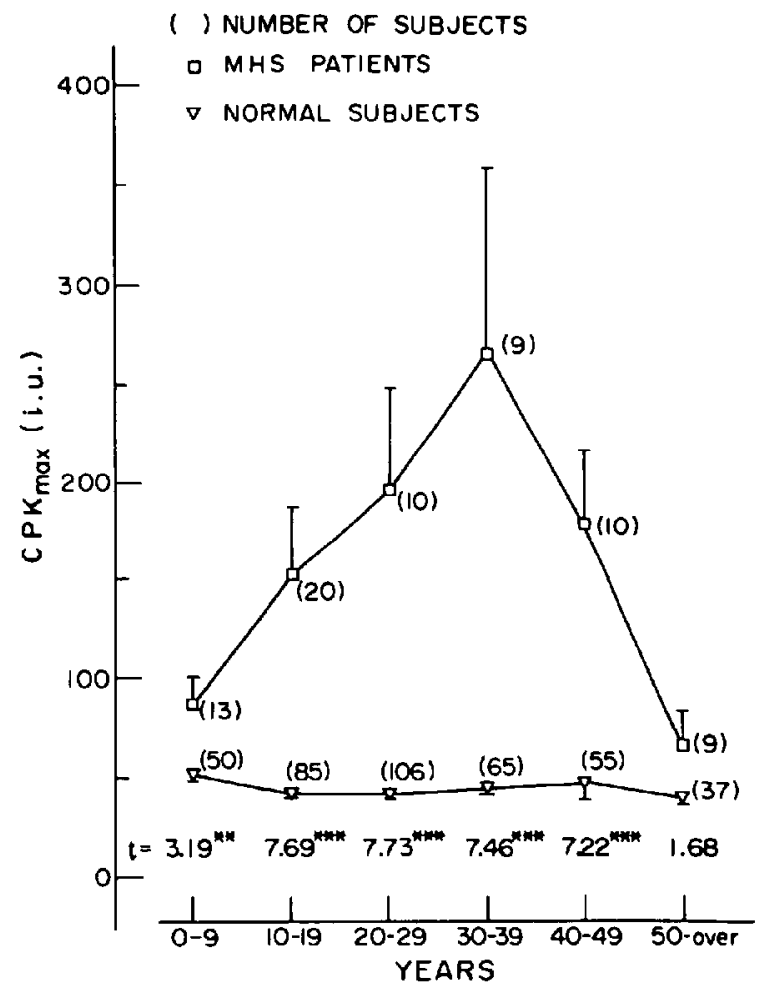

Ficure 2. Variation of maximum CPK levels with age in MHS and control subjects. Standard errors of the means are indicated. 
The incidence of muscle or musculoskeletal abnormalities was significantly greater in MHS than in normal volunteers with intermediate values seen for the near and distant relatives (Table V). In normal volunteers (Table V, Figure 3) CPK was virtually identical both in those with and in those without muscle or musculoskeletal abnormalities. In MHS patients and relatives serum CPK was significantly higher in those with than in those without muscle abnormalities. This correlation of a muscle abnormality with a high serum CPK was more marked in males than in females (Table V). Consideration of individual muscle abnormalities revealed that for each, the incidence and the mean CPK values were higher for the MHS patients than for the normal volunteers (Table VI).

Thus, average CPK levels in normal subjects depend on the sex of the individual but are not affected by age or by the incidence of muscle or musculoskeletal abnormalities. The logarithmic (but not the untransformed) observations can be approximately described by the normal distribution and, consequently, confidence limits can be established. The upper 99 per cent confidence limit for average CPK readings is 122 i.u. in males and 91.6 i.u. in females. This implies that 1 per cent of the normal subjects are expected, on the average, to have CPK levels exceeding these readings. In contrast, 12 of 23 affected males $(51$ per cent), and 6 of 13 affected females ( 46 per cent) between the ages of 10 and 49 who exhibited muscle or musculoskeletal abnormalities had CPKs higher than the critical levels. In the same age group, of patients not showing such abnormalities, the corresponding counts in males were two out of seven (18 per cent) and in females, two out of six ( 33 per cent). Outside this age group, only two out of 22 MHS subjects had elevated CPK levels.

\section{Studies of individual families}

Comparison of individual families revealed marked differences from one family to the next in CPK of susceptible patients and their relatives. In about 20 per cent of families, all members, including those who had had prior MH episodes had normal serum CPK. In several of these families, no rigidity occurred during previous anaesthetics in which pyrexia occurred, and only one known member could be detected per family (Figure 4). The defect in these individuals may not be hereditary, or it might be genetic, but could be either very mild or not involving the sarcolemma, at least not prior to anaesthesia.

In a very few of the families with normal CPK concentrations, rigidity was prominent but fever was modest during anaesthesia. Multiple cases, but no deaths, occurred in several of these latter clans (Figure 5). A possible explanation for this combination of events is a defect involving excitation-contraction coupling but not impairing the sarcolemma prior to anaesthesia.

In about 35 per cent of families, inconsistent CPK readings were observed in some members. The elevations were sometimes small (Figures 6 and 7), were not always reproducible from one day to the next in the same subject (Figure 6), and in some instances did not follow an autosomal dominant pattern (Figure 6). For example, in some instances both parents of the proband and relatives of both parents of the proband had elevated serum CPK values. In other cases, the CPK levels in the offspring of a proband with a high serum CPK and a normal individual with a normal serum CPK were intermediate between the two parental levels. 
CANADIAN ANAESTHETISTS' SOCIETY JOURNAL

TABLE $V$

Maximum CPK Levels in the Presence and Absence of Muscle AbNoRmalities

\begin{tabular}{|c|c|c|c|}
\hline & With muscle disease & No muscle disease & $t \uparrow$ \\
\hline MHS patients & $\begin{array}{cc}\text { Male } & 187.2 \dagger \\
+ & (182.5) \ddagger \\
\text { Female } & (26.3) \S \\
& (48) \| \\
\text { Male } & 212.2 \\
& (202.9) \\
& (39.0) \\
& (27) \\
\text { Female } & 155.0 \\
& (151.0) \\
& (33.0) \\
& (21)\end{array}$ & $\begin{array}{cc}\text { Male } & 84.0 \\
+ & (45.5) \\
\text { Female } & (9.3) \\
& (24) \\
\text { Male } & 95.4 \\
& (51.4) \\
& (14.3) \\
& (13) \\
\text { Female } & 70.5 \\
& (34.8) \\
& (10.5) \\
& (11)\end{array}$ & $\begin{array}{l}2.21^{*} \\
2.13^{*}\end{array}$ \\
\hline $\begin{array}{l}\text { lst degree } \\
\text { relatives }\end{array}$ & $\begin{array}{cc}\text { Male } & 129.7 \\
+ & (170.8) \\
\text { Female } & (17.7) \\
& (93) \\
\text { Male } & 123.1 \\
& (132.1) \\
& (17.5) \\
& (57) \\
\text { Female } & 140.3 \\
& (220.3) \\
& (36.7) \\
& (36)\end{array}$ & $\begin{array}{cc}\text { Male } & 72.5 \\
+ & (74.2) \\
\text { Female } & (5.8) \\
& (166) \\
\text { Male } & 77.2 \\
& (54.3) \\
& (6.0) \\
& (71) \\
\text { Female } & 68.0 \\
& (89.2) \\
& (9.7) \\
& (85)\end{array}$ & $\begin{array}{l}3.95^{* * *} \\
2.44^{*} \\
2.73^{* *}\end{array}$ \\
\hline $\begin{array}{l}\text { 2nd and } 3 \text { rd } \\
\text { degree } \\
\text { relatives }\end{array}$ & $\begin{array}{cc}\text { Male } & 81.6 \\
+ & (100.6) \\
\text { Female } & (11.5) \\
& (76) \\
\text { Male } & 106.5 \\
& (122.1) \\
& (18.4) \\
& (44) \\
\text { Female } & 47.5 \\
& (41.9) \\
& (7.4) \\
& (32)\end{array}$ & $\begin{array}{cc}\text { Male } & 57.7 \\
+ & (50.2) \\
\text { Female } & (2.5) \\
& (390) \\
\text { Male } & 68.4 \\
& (61.1) \\
& (4.5) \\
& (187) \\
\text { Female } & 47.9 \\
& (34.9) \\
& (2.4) \\
& (203)\end{array}$ & $\begin{array}{l}2.94^{* *} \\
0.86 \text { n.s. }\end{array}$ \\
\hline $\begin{array}{l}\text { Normal } \\
\text { subjects }\end{array}$ & $\begin{array}{cc}\text { Male } & 40.9 \\
+ & (25.7) \\
\text { Female } & (4.5) \\
& (32) \\
\text { Male } & 47.3 \\
& (33.1) \\
& (8.5) \\
& (15) \\
\text { Female } & 35.3 \\
& (15.8) \\
& (3.8) \\
& (17)\end{array}$ & $\begin{array}{cc}\text { Male } & 43.5 \\
+ & (30.2) \\
\text { Female } & (1.5) \\
& (413) \\
\text { Male } & 50.2 \\
& (37.7) \\
& (2.8) \\
& (185) \\
\text { Female } & 38.0 \\
& (21.0) \\
& (1.4) \\
& (228)\end{array}$ & 0.59 n.s. \\
\hline
\end{tabular}

IStatistical tests ( $t$-values) are based on comparisons of the logarithmic values. tMean of maximal $C P K$ values in international units.

$\ddagger$ Standard deviation.

Standard error of mean.

\|Number of subjects.

n.s. $P \geqslant 0.05$.

$* P<0.05$

${ }^{* *} P<0.01$.

*** $P<0.001$. 


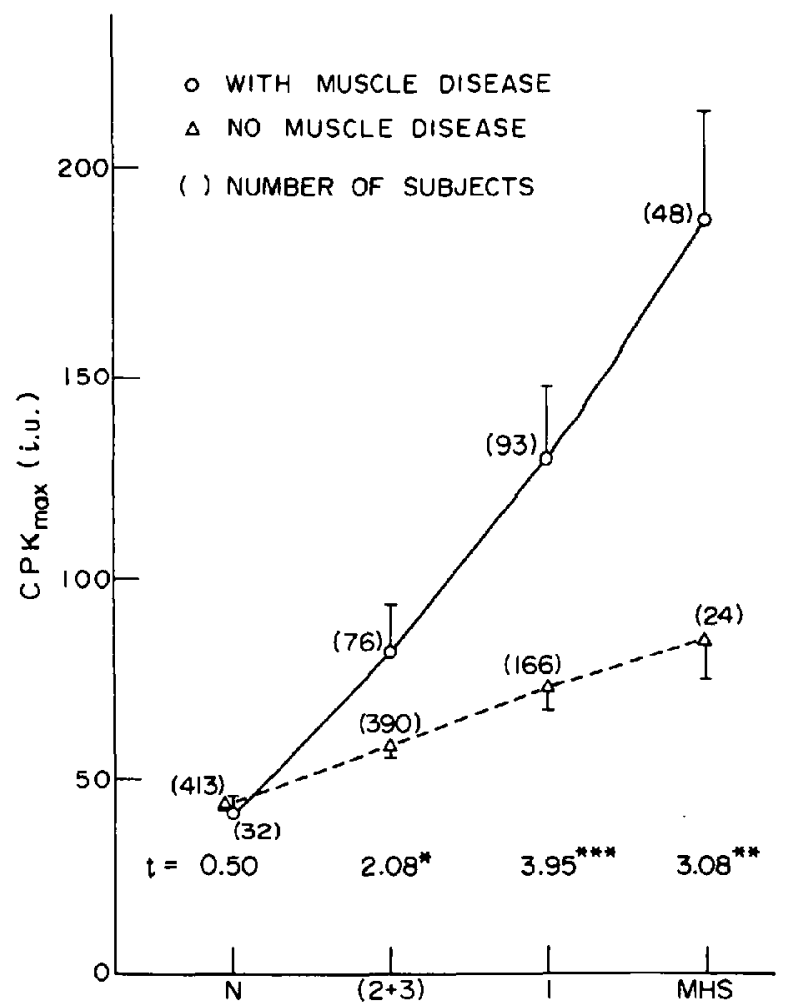

Figure 3. Maximum CPK levels in malignant hyperthermia susceptible (MHS) subjects, their first-, and second- together with third-degree $(2+3)$ relatives and in normal $(N)$ individuals with and without muscle and musculoskeletal abnormalities. Standard errors of the means are shown.

Recent advances in the understanding of the mode of inheritance of MH has been discussed in detail in a recent publication by Kalow, et al. ${ }^{\text {a2 }}$

Finally, in some of the same families, muscle biopsies revealed several persons (for example, the mother of the proband in pedigree NNB (Figure 6) and the proband in pedigree OOL (Figure 7)) with normal or near normal serum CPKs to have isometric muscle contractures and skeletal muscle microscopic findings characteristic of $\mathrm{MH}$.

In the remaining 45 per cent of the families, the MHS patients and some close relativese did have serum CPKs which were clearly higher than those of the remaining relatives and of unrelated individuals (Figures 8 and 9). The elevations followed an autosomal dominant distribution and were reasonably reproducible from one sampling to the next in the same individual. Positive muscle biopsies occurred only in those individuals with high CPKs. For these families, therefore, serum CPK was a useful screening procedure. Nevertheless, even in these families, some individuals with normal serum CPK had clinical muscle abnormalities.

\section{Observations on Previous General Anaesthetics}

The mortality of the 72 MHS cases examined was 38.8 per cent. This surprisingly low value may have been due in part to the fact that families of fatal cases are 


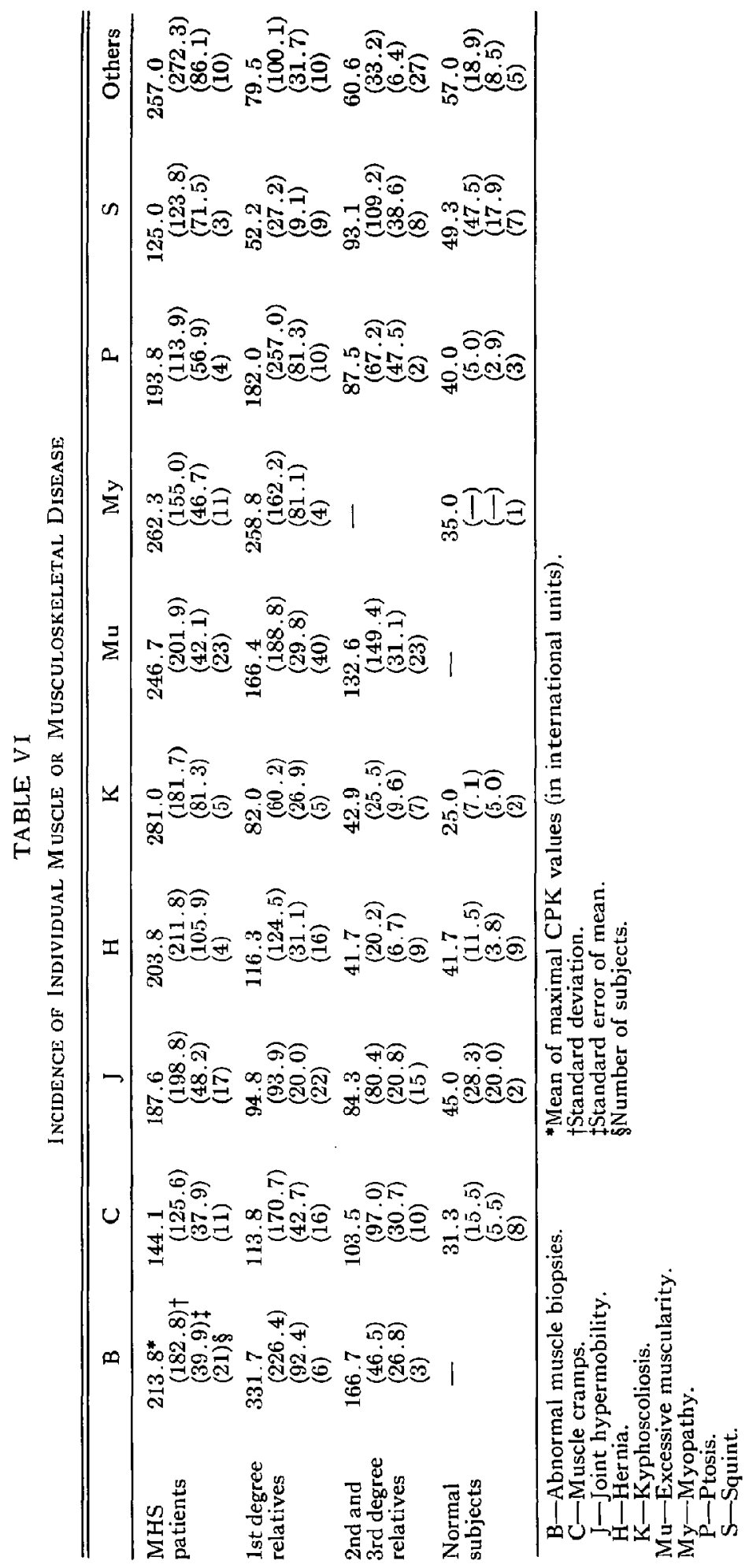


Paedigree OLJ

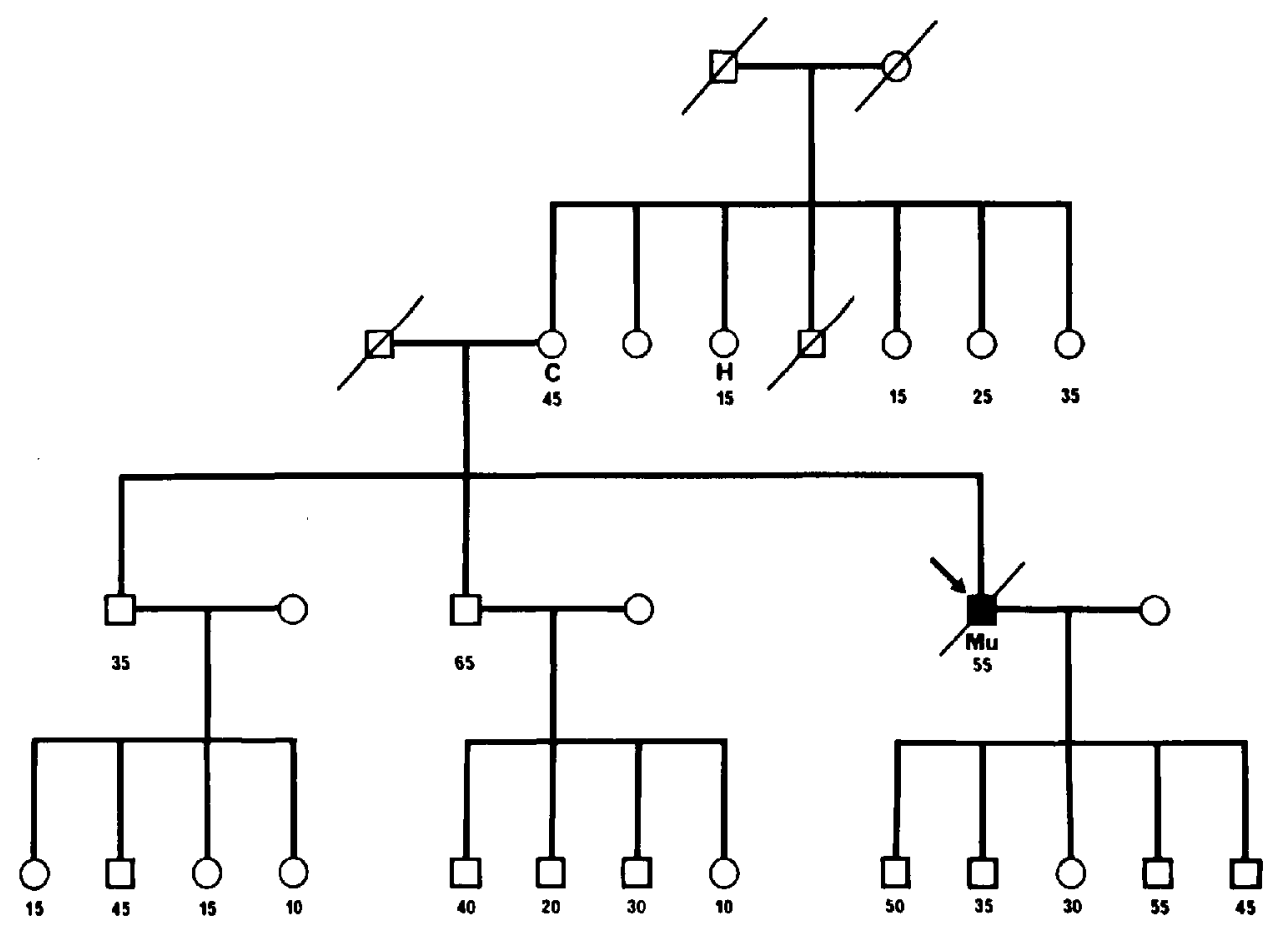

Figures 4-9:

$\square$ Normal male

Affected female

Died of malignant hyperthermia

$\varnothing$ Died of causes other than malignant

hyperthermia

$\searrow$ Proband

$\otimes$ Unrelated individual

" 45 " Digits refer to CPK in international units

C Muscle cramps

D Joint dislocation

H Congenital inguinal hernia

J Joint hypermobility

K Kyphoscoliosis

Mu Excessive muscularity

My Muscle biopsy positive for malignant

hyperthermia

P Ptosis

Figure 4. Pedigree of a family in which one member suffered a fatal, non-rigid MH reaction.

\section{Paedigree OGR}

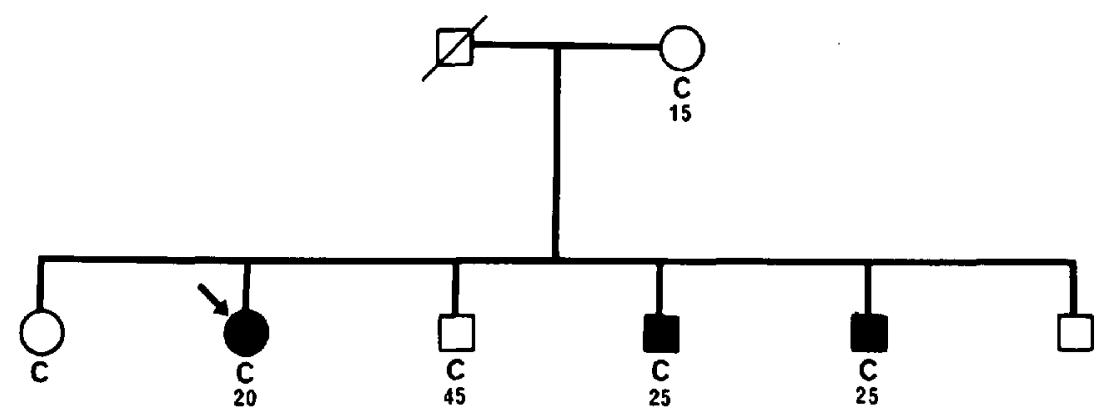

Figure 5. Pedigree of a family in which three siblings suffered non-fatal, rigid MH reactions. 

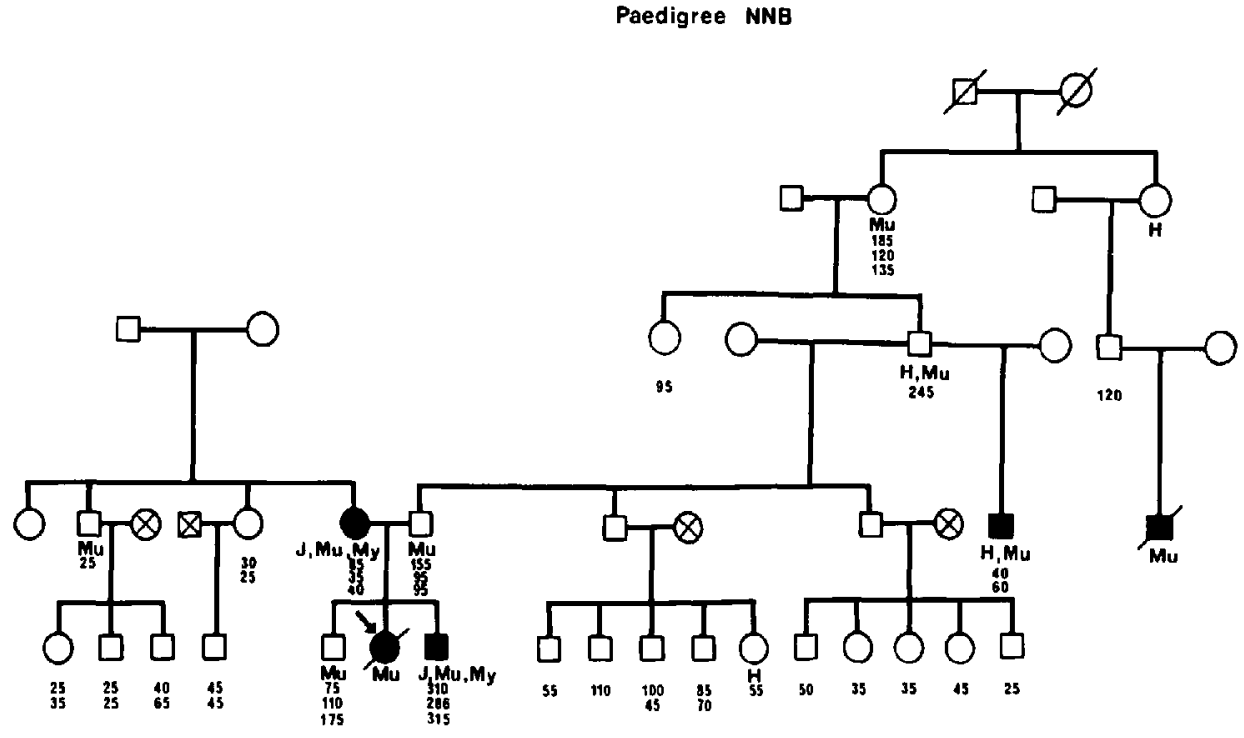

FICUnE 6. Pedigree of an MH family exhibiting atypical inheritance. The proband died during a rigid $\mathrm{MH}$ reaction. The mother survived a similar rigid $\mathrm{MH}$ reaction. A second cousin of the proband's father died during a rigid MH crisis. The mother, the proband's brother and paternal step-uncle all had muscle biopsies positive for malignant hyperthermia. The mother exhibited a moderate elevation of the serum CPK on one occasion. Both brothers, the father, the grandfather and the great-grandmother of the proband displayed significant elevations of the serum CPK.

\section{Paedigree OOL}

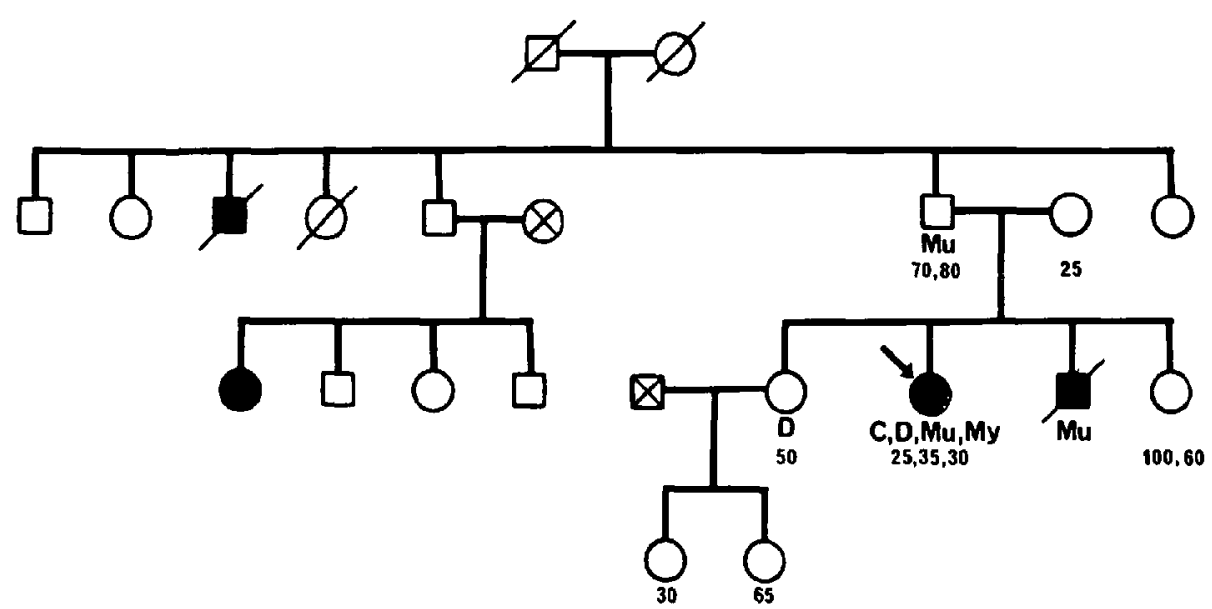

Figure 7. Pedigree of a family in which four individuals have had rigid MH reactions (two fatal and two non-fatal). Serum CPK levels in the proband (who also had a muscle biopsy positive for malignant hyperthermia) were normal on all occasions. Serum CPK values in other relatives were either normal or only slightly elevated. 


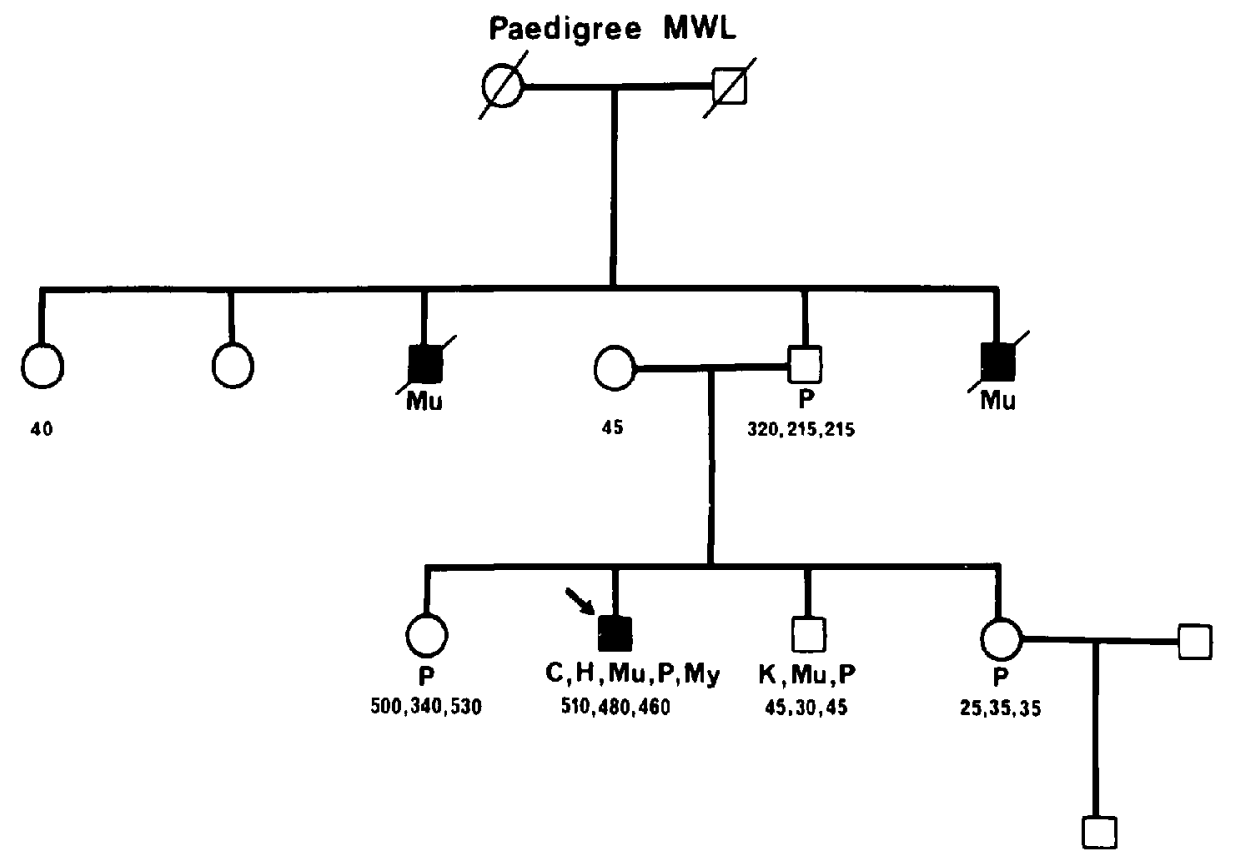

Figure 8. Pedigree of a family in which three individuals developed rigid MH during anaesthesia (two fatal and one non-fatal). The one survivor had a biopsy positive for malignant hyperthermia. He, his sibling and his father had, on repeated occasions, a marked elevation of the serum CPK. Muscle abnormalities were present not only in three individuals but also in two other siblings of the proband whose serum CPKs on all occasions were in the normal range.

\section{Paedigree IGR}

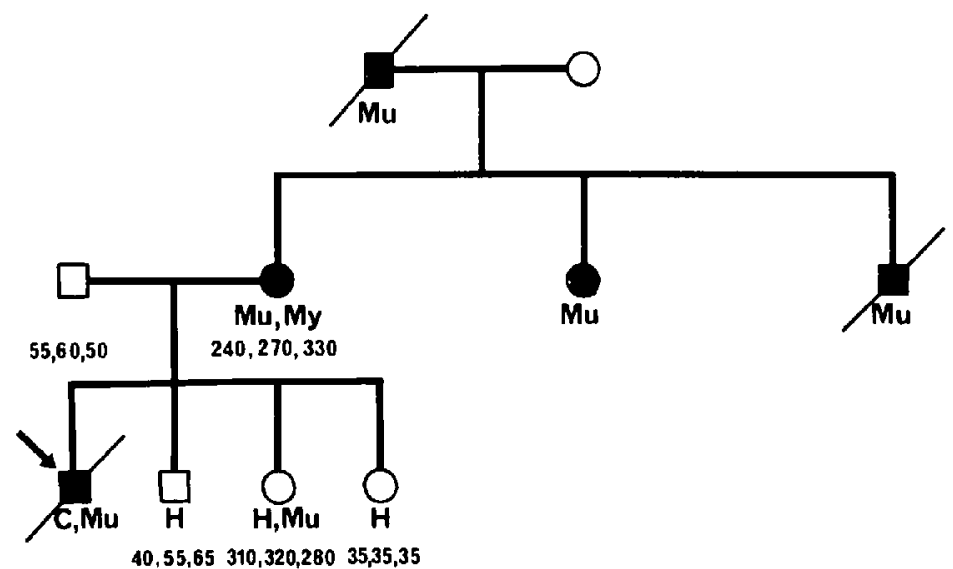

Figune 9. Pedigree of a family containing five individuals known to have had rigid MH crisis. One survivor had a biopsy positive for malignant hyperthermia. This individual and one daughter displayed significant serum CPK elevations on three subsequent occasions. They were both extremely muscular and the daughter had a congenital inguinal hernia. Two other offspring who had normal CPKs also had congenital inquinal herniae but normal muscularity. 
sometimes not referred to us, partly because communication by the attending physician with the patient's relatives is sometimes less than ideal and partly because relatives in such families are, not infrequently, so emotionally upset that they refuse further contact with doctors.

The maximum temperature attained during a hyperthermic anaesthetic should be expected to be dependent at least in part on the severity of the muscle defect. Since the elevation of the serum CPK is a reflection of this defect, we expected to detect a positive correlation between maximum temperature during $\mathrm{MH}$ crises and post-recovery serum CPK. Nevertheless, we did observe such a relationship: the correlation coefficient describing the association between the highest observed $\mathrm{CPK}$ level $(\mathrm{CPK} / \mathrm{max})$ and the maximum temperature elevation is in the 37 subjects, $r=0.32$. Similar statistically not significant correlations have been found by separating the data for the two sexes. Apparently, maximum temperature is more influenced by environmental factors (e.g. duration of anaesthesia, triggering agents and therapy during crises) and in variations in exercise or alcohol ingestion (at the time of CPK testing).

The number of previous anaesthetics administered in each of the four patient categories was compared. In the MHS group all patients had had, by definition, at least one anaesthetic. In order to avoid bias, therefore, in the other categories, we counted only those individuals who had had at least one anaesthetic. Anaesthetics comprising conduction or regional techniques were also included since in the MHS category, once the hyperthermic anaesthetic had occurred, anaesthesia tended thereafter to be by one of these techniques. Rather surprisingly, we observed that in both sexes (Table VII) and in all ages (Table VIII), MHS persons had had fewer anaesthetics than had normal persons. First-, second- and thirddegree relatives on the whole had had anaesthetics intermediate in number between MHS and normal individuals. Initially we thought that this difference was due to physician reluctance to anaesthetize known MHS patients. Investigation, however, showed that none of the MHS patients were suffering from any neglected surgical problems. Rather they appeared to be a fitter group with reduced susceptibility to malignancies and psychosomatic surgical problems such as peptic ulcers. In fact, the majority of anaesthetics were administered for trauma, repair of local-

TABLE VII

Numbers of Previous Anaesthetics in MHS Patients, in Relatives and in NoRmal SUbjects

\begin{tabular}{lccccc}
\hline \hline & \multicolumn{2}{c}{ Males } & & \multicolumn{2}{c}{ Females } \\
\cline { 2 - 3 } $\begin{array}{l}\text { No. of subjects } \\
\text { with at least } \\
\text { one anaesthetic }\end{array}$ & $\begin{array}{c}\text { No. of } \\
\text { anaesthetics } \\
\text { per person }\end{array}$ & & $\begin{array}{c}\text { No. of subjects } \\
\text { with at least } \\
\text { one a naesthetic }\end{array}$ & $\begin{array}{c}\text { No. of } \\
\text { anaesthetics } \\
\text { per person }\end{array}$ \\
\hline $\begin{array}{l}\text { Subject group } \\
\begin{array}{l}\text { 1st degree } \\
\text { relatives }\end{array}\end{array}$ & 70 & 1.30 & 54 & 1.33 \\
$\begin{array}{l}\text { 2nd and 3rd } \\
\text { degree }\end{array}$ & 61 & 1.44 & 51 & 2.12 \\
$\begin{array}{l}\text { relatives } \\
\text { Normal subjects }\end{array}$ & 60 & 1.27 & & 75 & 1.58 \\
\hline
\end{tabular}




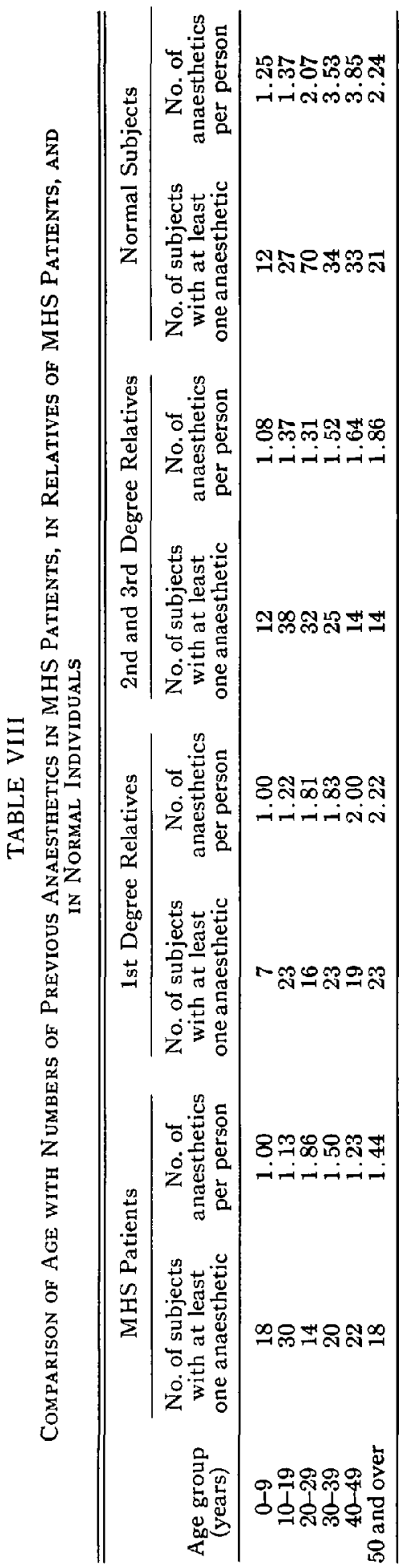


ized muscle weaknesses (hernia, kyphoscoliosis, club foot, joint dislocation, squint and ptosis), or for infection (appendectomy and tonsillectomy).

The number of anaesthetics associated with $\mathrm{MH}$ crises per family per year, prior to commencement of investigation was 0.70 , and subsequent to commencement of investigation was 0.05 . This marked reduction in incidence of $\mathrm{MH}$ crises is gratifying evidence of the beneficial value of investigation and counselling of all known relatives of MHS patients.

\section{Patient Counselling}

We issued Medic-Alert bracelets to the following: (1) all patients who had had a previous $\mathrm{MH}$ crisis; (2) all those who had a positive muscle biopsy; (3) all first degree relatives of (1) and (2); (4) all relatives of (1) and (2) who had a high $\mathrm{CPK}$ on one or more occasion; and (5) all relatives of (1) and (2) who displayed clinical muscle abnormalities. The bracelets were labelled: No GENERAL anAEsthetics or MUSCle RELAXaNts: MaLignaNt hyperthermia. A label reading No POTENT INHALATIONAL AGENTS OR MUSCLE RELAXANTS: MALIGNANT HYPERTHERMIA would have been preferable. This proved to be impossible, however, since the number of extra letters required would not fit into the limited space available on the Medic-Alert bracelet.

Patients to whom Medic-Alert bracelets were issued were counselled regarding the necessity of avoiding triggering agents and they were reassured about the ready availability of safe and effective agents. Counselling was carried out by both personal communication and by means of a monograph entitled "Answers to Some Questions About Malignant Hyperthermia." Pedigrees showing CPK values and muscle abnormalities for individual patients were sent to each family and, when requested, to appropriate family physicians.

\section{Conclusion}

In normal subjects sex was the only factor influencing serum CPK levels (i.e. values were significantly higher in males than females). In MHS persons two factors were found to influence the CPK levels - age and concomitant clinical muscle abnormalities. Thus, in MHS persons not only were CPK levels substantially higher between the ages of 10 and 49 than below or above these ages, but also were significantly higher in those with than in those without clinical muscle abnormalities. We found serum CPK measurement to be of no benefit in identifying $\mathrm{MH}$ in subjects without a family history of $\mathrm{MH}$. This was because muscle damaging conditions other than $\mathrm{MH}$ are known to also significantly elevate the serum CPK and because some persons with $\mathrm{MH}$ were found to have normal serum CPK.

Even in individual MHS families, the CPK by itself proved to be of only limited value in identifying afflicted persons. In only 45 per cent of families did serum CPK elevations prove to be of real diagnostic value. In 20 per cent of families serum CPK levels were normal in all members. Inconsistent levels were observed in the re- 
maining 35 per cent of families. Nevertheless, accuracy of identification of MHS individuals was considerably greater when both a high CPK and muscle or musculoskeletal abnormalities were present in the same person. Such a combination was most apt to occur in males between the ages of 10 and 49. Certain diagnosis in suspected individuals nevertheless still requires a history of a previous $\mathrm{MH}$ episode or a positive muscle biopsy. All suspected individuals should always wear a MedicAlert bracelet and should never be given triggering agents during anaesthesia.

\section{SUMMARY}

We investigated 56 families afflicted with malignant hyperpyrexia. One hundred and twenty-four individuals within these families had had an episode of malignant hyperthermia, of whom we saw seventy-two. Serum creatine phosphokinase (CPK) was statistically higher in affected individuals and in close relatives than in normal volunteers. The magnitude of the serum CPK elevations varied significantly between families. While in some families the serum CPK was clearly elevated in affected individuals, in other families the serum CPK was normal or only moderately or inconsistently raised. In these latter families serum CPK measurement was therefore of little or no value in identifying afflicted members.

The incidence of musculoskeletal abnormalities was greater in affected individuals and in close relatives than in the general population. Thus, the concomitant presence of both a high serum CPK and a musculoskeletal abnormality in an individual belonging to a family known to be susceptible to malignant hyperthermia was a better indicator of the $\mathrm{MH}$ trait than was the presence of only one of these parameters.

For reasons which we do not fully understand, MHS individuals were found to require fewer anaesthetics than normal persons. The incidence of $\mathrm{MH}$ crises within each family fell significantly following investigation, counselling, and issuance of Medic-Alert bracelets.

\section{RÉSUMÉ}

Notre étude a porté sur cinquant-six familles. Cent vingt-quatre membres de ces familles avaient présenté des épisodes d'hyperthermie maligne et nous avons pu investiguer soixante-douze de ceux-ci.

Nous avons retrouvé des taux de CPK sériques plus élevés chez des individus affectés et leurs proches parents que chez les volontaires normaux. Le degré d'élévation des CPK variait cependant d'une famille à l'autre. Alors que dans certaines familles les individus affectés présentaient des taux nettement élevés, dans d'autres familles, des taux normaux ou peu élevés étaient retrouvés chez les sujets affectés. Dans ce second groupe de familles, la détermination des CPK sériques n'est donc pas un bon moyen de dépister les individus susceptibles de présenter un épisode d'hyperthermie maligne.

L'incidence des anomalies musculo-squelettiques était plus élevés chez les sujets affectés et chez leurs proches parents que l'incidence de ces anomalies au sein de la population générale. Donc, la présence concomitante d'un taux élevé de 
CPK et d'anomalies musculo-squelettiques retrouvée chez un sujet membre d'une famille présentant une histoire d'hyperthermie maligne est un meilleur indicateur de susceptibilité à l'hyperthermie qu'un seul de ces paramètres isolés.

Pour des raisons encore mal comprises, les sujets susceptibles à l'hyperthermie maligne requièrent moins d'anesthésiques que les sujets normaux.

L'incidence des épisodes d'hyperthermie maligne a diminué de façon significative dans les familles investiguées, conseillées, et auxquelles on avait remis des bracelets Medic-Alert.

\section{ACKNOWLEDGMENTS}

The authors wish to thank Dr. John Brebner, Dr. John Relton and Dr. R. A. Gordon for their help in the final preparation of this manuscript.

This work was supported by grants from the Ontario Ministry of Health, Medical Research Council of Canada (Grant MA-5765) and the PSI Foundation.

\section{REFERENCES}

1. FujIE, Y. Distribution of creatine phosphokinase among mammalian tissues. Seitai no Kagaku 11: 207 (1960).

2. Oliver, I.T. A spectrophotometric method for the determination of creatine phosphokinase and myokinase. Biochem. J. 61:116 (1955).

3. Tanzer, M.L. \& Gilvarg, C. Creatine and creatine kinase measurement. J. Biol, Chem. 234: 3201 (1959).

4. Bulcke, J.A. \& Sherwin, A.L. Organ specificity of creatine phosphokinase muscle isoenzyme. Immunochemistry 6:681 (1969).

5. Baskin, R.J. \& Deamer, D.W. A membrane-bound creatine phosphokinase in fragmented sarcoplasmic reticulum. J. Biol. Chem. 245: 1345 (1970).

6. Oscai, L.B. \& Holloszy, J.O. Biochemical adaptations in muscle. II Response of mitochondrial adenosine triphosphatase, creatine phosphokinase and adenylate kinase activities in skeletal muscle to exercise. J. Biol. Chem. 246; 6968 (1971).

7. Lohmann, $K$. Uber die enzymatische aufspaltung der kreatinphosphosaure; zugleich ein beitrag zum chemismus der muskelkontraktion. Biochem. Z., 271; 264 (1934).

8. Britt, B.A., Kalow, W., Cordon, A., Humphrey, J.G., \& Rewcastle, N.B. Malignant hyperthermia: an investigation of five patients. Canad. Anaesth. Soc. J. 20:431 (1973).

9. SANDow, A. Excitation-contraction coupling in skeletal muscle. Pharmac. Rev. 17: 265 (1965).

10. Sandow, A. Skeletal muscle. Ann. Rev. Physiol. 32: 87 (1970).

11. Perry, S.V. The role of myosin in muscular contraction. Society for Experimental Biology, Aspects of Cell Motility, 22: 1 (1968).

12. Weber, A. \& Winicur, S. Dependence of superprecipitation of actomyosin on the concentration of ionized calcium. Fed. Proc. 20:300 (1961).

13. Weber, A. \& Henz, R. Requirement for calcium in the synaeresis of myofibrils. Biochem. Biophys. Res. Comm. 6: 364 ( 1961 ).

14. Ebasht, S. \& Endo, M. Calcium ion and muscle contraction. Progr. Biophys. Mol. Biol. 18: $123(1968)$.

15. Han, M.H. \& Benson, E.S. Conformational changes in troponin induced by $\mathrm{Ca}^{++}$. Biochem. Biophys. Res. Comm. 28: 378 (1970).

16. Wakabayashi, T. \& Ebashi, S. Reversible change in physical state of troponin induced by calcium ion. J. Biochem. 64: 731 (1968).

17. Winecrad, S. The location of muscle calcium with respect to the myofibrils. J. Gen. Physiol. 48: 997 (1965).

18. Yasui, B., Fuchs, F., \& Briggs, F.N. The role of the sulfhydryl groups of tropomyosin and troponin in the calcium control of actomyosin contractility. J. Biol. Chem. 243: 735 (1968). 
19. Fowler, W.M., Chowdhury, S.R., Pearson, C.M., Gardner, G., \& Bratton, R. Changes in serum enzyme levels after exercise in trained and untrained subjects. J. Appl. Physiol. 17: 943 (1962).

20. Griffiths, P.D. Serum levels of ATP, creatine phosphotransferase and creatine kinase. The normal range and effect of muscular activity. Clin. Chim. Acta 13: 413 (1966).

21. KING, J.O. \& $Z_{A P F}, P$. A review of the value of creatine phosphokinase estimations in clinical medicine. Med. J. Aust. 1: 699 ( 1972).

22. Hess, J.W., MacDonald, R.P., Frederick, R.J., Jones, R.N., Neely, J., \& Gross, D. Serum creatine phosphokinase (CPK) activity in disorders of heart and skeletal muscle. Ann. Int. Med. $61: 1015$ (1964).

23. VAN der VEen, K.J. \& Willebrands, A.F. Isoenzymes of creatine phosphokinase in tissue extracts and in normal and pathological sera. Clin. Chim. Acta 13: 312 (1966).

24. Kar, N.C. \& Pearson, C.M. Creatine phosphokinase isoenzymes in muscle in human myopathies. Am. J. Clin. Pathol. 43: 207 (1965).

25. McCnimmon, A. \& Lewin, E. Serum creatine phosphokinase: a useful tool in muscle disease. Am. J. Med. Tech. 33: 269 (1967).

26. Karpati, G. \& Sherwin, A.L. Immunohistochemical study of creatine phasphokinase in pathological human muscle. J. Neurol. Sci. 14: 153 (1971)

27. Thomson, W.H.S. Serum enzyme studies in inherited disease of skeletal muscle. Clin. Chim. Acta 35:183 (1971).

28. Pearce, J.M.S., Pennington, R.J., \& Walton, J.N. Serum enzyme studies in muscle disease. Part II. Serum creatine kinase activity in muscular dystrophy and other myopathic and neuropathic disorders. J. Neurol. Neurosurg. Psychiat. 27: 96 (1964).

29. Williams, E.R. \& Bruford, A. Creatine phosphokinase in motor neurone disease. Clin. Chim. Acta 69: 53 (1967).

30. Cao, A., DeVirgilis, S., Lippi, C., \& Trabalza, N. Creatine kinase isoenzymes in serum of children with neurological disorders. Clin. Chim. Acta 23: 475 (1969).

31. Sherwin, A.L., Nornis, J.W., \& Bulcke, J.A. Spinal fluid creatine kinase in neurologic disease. Neurology 19: 993 (1969).

32. Meltzer, H. Muscle enzyme release in the acute psychoses. Arch. Gen. Psychiat. 21: 102 (1969)

33. Nygren, A. Muscular involvement in acutely intoxicated alcoholics revealed by elevated serum CPK activity. Opusc. Med. Bd. 10: 329 (1965)

34. Fleisher, G.A. \& McConahey, W.M. Serum creatine kinase, lactic dehydrogenase, and glutamic-oxalacetic transaminase in thyroid diseases and pregnancy. J. Lab. Clin. Med. 64: 857 (1964).

35. Graig, F.A. \& Ross, G. Serum creatine phosphokinase in thyroid disease. Metabolism 12 : 57 (1963).

36. Meltzer, H.Y. \& Margulies, P. Release of creatine phosphokinase from muscle. I. Effect of polymysin B, compound 48/80, and serotonin. Biochem. Pharmacol. 20: 3501 (1971).

37. Innes, R.K.R. \& Stromme, J.H. Rise in serum creatine phosphokinase associated with agents used in anaesthesia. Brit. J. Anaesth. 45: 185 (1973).

38. TAMmisto, T. \& AIRAKSINEN, M. Increase of creatine kinase activity in serum as sign of muscular injury caused by intermittently administered suxamethonium during halothane anaesthesia. Brit. J. Anaesth. 38: 510 (1966).

39. Wolfe, R.R., Rutrenberc, H.D., \& Moss, A.J. Serum creatine phosphokinase levels in children undergoing cardiac catheterization. J. Pediat. 77:52 (1970).

40. Denbonough, M.A., Hudson, M.C., Fonster, J.F.A., Carter, N.G., \& Zapf, P. Biochemical changes in malignant hyperpyrexia. Lancet $i i: 1137$ (1970).

41. Denborough, M.A., Fonster, J.F.A., Hunson, M.C., Carter, N.G., \& Zapf, P. Malignant hyperpyrexia - a serious, preventable complication of general anaesthesia. Australasian Congress of Anaesthesiology, Melbourne, Australia (1970).

42. IsAacs, H. \& BARLow, M.B. The genetic background to malignant hyperpyrexia revealed by serum creatine phosphokinase estimations in asymptomatic relatives. Brit. J. Anaesth. 42: 1078 (1970).

43. IsaAcs, H. \& BARLow, M.B. Malignant hyperpyrexia - further muscle studies in asymptomatic carriers identified by creatine phosphokinase screening. J. Neurol. Neurosurg. Psychiat. 36: 228 (1973).

44. IsaAcs, H. \& Barlow, M.B. Central core disease associated with elevated creatine phosphokinase levels - two members of a family known to be susceptible to malignant hyperpyrexia. South African Med. J. 48: 640 (1974). 
45. IsaAcs, H. \& Barlow, M.B. Malignant hyperpyrexia occurring in a second Johannesburg family. Brit. J. Anaesth. 45: 901 (1973).

46. Aldrete, J.A., Padfield, A., Solomons, C.C., \& Rebright, M.W. Possible predictive tests for malignant hyperthermia during anaesthesia. J.A.M.A. 215: 1465 (1971).

47. Moulds, R.F.W. \& Denbonough, M.A. Biochemical basis of malignant hyperpyrexia. Brit. Med. J. 2: 245 (1974)

48. Zsigmond, E.K., Starkweather, W.H., Duboff, G.S., \& Flynn, K. CPK and malignant hyperthermia. Anesth. Analg. 51: 220 (1972)

49. Kyei-Mensaf, K., Tyrrell, J.H., \& Sumner, D.W. Clinical and genetic aspects of malignant hyperpyrexia. Proc. Roy. Soc. Med. 66: 63 (1973).

50. Larafd, D.G., Rice, C.P., Robinson, R., Spencer, W., \& Westhead, R.A. Malignant hyperthermia: a study of an affected family. Brit. J. Anaesth. 44: 93 (1972).

51. WedLeY, J.R. \& JAFFE, E.C. Malignant hyperpyrexia and the dental outpatient. Anaesthesia 28: $146(1973)$.

52. Ellis, F.R., Keaney, N.P.,Harriman, D.G.F., Sumner, D.W., Kyej-Mensah, K., Tyrrell, J.H., Hargenaves, J.B., Parikh, R.K., \& Mulrooney, P.L. Screening for malignant hyperpyrexia. Brit. Med. J. 3: 559 ( 1972 ).

53. Ellis, F.R., Keaney, N.P., \& Harriman, D.G.F. Histopathological and neuropharmacological aspects of malignant hyperpyrexia. Proc. Roy. Soc. Med. 66: 66 (1973).

54. Moulds, R.F.W. \& Denborough, M.A. Identification of susceptibility to malignant hyperpyrexia. Brit. Med. J. 2: 245 (1974).

55. Kelstrup, J., Reske-Nielsen, E., HaAse, J., \& Jorni, J. Malignant hyperthermia in a family: a clinical and serological investigation of 139 members. Acta anaesth. scand. 18 : 58 ( 1974).

56. King, J.O., Denborough, M.A., \& ZAPF, P. Inheritance of malignant hyperpyrexia. Lancet 1: 365 ( 1972)

57. Thomson, W.H.S. An investigation of physical factors influencing the behaviour in vitro of serum creatine phosphokinase and other enzymes. Clin. Chim. Acta 23: 105 (1969).

58. Rosalki, S.B. An improved procedure for serum creatine and phosphokinase determination. J. Lab. Clin. Med. 69: 696 (1967).

59. Calbiochem CPK Reagents. Document No. LO3012, 1974.

60. Morgenstern, S., Oklander, M., Auerbach, J., Kaufman, J., \& Klein, B. Automated determination of serum glutamic oxaloacetic transaminase. Clin. Chem. 12:95 (1966).

61. WROBlewskr, F. \& LADUE, J.S. Lactic dehydrogenase activity in blood. Proc. Soc. Exp. Biol. Med. 90: 210 (1955).

62. Kalow, W., Britt, B.A., \& Richter, A. The caffeine test of isolated human muscle in relation to malignant hyperthermia. Human Genetics, in press 1976. 